\title{
Nursing care provided to persons deprived of liberty in the hospital environment
}

\author{
Assistência de enfermagem prestada às pessoas privadas de liberdade no ambiente hospitalar \\ Atención de enfermería a las personas privadas de libertad en el ambiente hospitalário
}

Polyanna Bezerra Alves da Silva'

ORCID: 0000-0002-4291-0243

Mayara Lima Barbosa"

ORCID: 0000-0002-8063-7903

Lannuzya Veríssimo e Oliveira"

ORCID: 0000-0002-6881-898X

Gabriela Maria Cavalcanti Costa"'

ORCID: 0000-0003-4466-6886

' Universidade Estadual de Pernambuco. Recife, Pernambuco, Brazil.

"Universidade Federal do Rio Grande do Norte. Natal,

Rio Grande do Norte, Brazil.

I" Universidade Estadual da Paraíba. Campina Grande,

Paraíba, Brazil.

How to cite this article: Silva PBA, Barbosa ML, Oliveira LV, Costa GMC. Nursing care provided to persons deprived of liberty in the hospital environment. Rev Bras Enferm. 2020;73(3):e20170809. doi: http://dx.doi.org/10.1590/0034-7167-2017-0809

\section{Corresponding author:}

Polyanna Bezerra Alves da Silva

E-mail: polyannabezerra@yahoo.com.br

EDITOR IN CHIEF: Dulce Aparecida Barbosa ASSOCIATE EDITOR: Alexandre Balsanelli

Submission: 01-10-2018

Approval: 05-03-2019

\begin{abstract}
Objectives: To describe the nursing care provided to people deprived of liberty (PDL) in the hospital environment. Methods: An exploratory-descriptive study with a qualitative approach, conducted with 38 nursing professionals in three regional hospitals located in the Northeast of Brazil, between March and July of 2016. Content analysis was performed on the data. Results: Two categories emerged from the analysis: nursing care provided to people deprived of liberty in the hospital setting and self-evaluation of nursing care provided to PDL. Final considerations: The nursing care delivered to people deprived of liberty in the hospital environment is limited to technical procedures, revealing a fragmented work process that falls short of the standards of public policies. We found that structural deficiency, particularly regarding safety in the hospital environment, associated with lack of professional training to deal with this clientele, make nursing care difficult in this context. Descriptors: Nursing Care; Hospital Care; Prisoners; Prisons; Public Health.
\end{abstract}

\section{RESUMO}

Objetivos: Descrever a assistência de enfermagem prestada às pessoas privadas de liberdade (PPL) no ambiente hospitalar. Métodos: Estudo exploratório-descritivo com abordagem qualitativa, realizado com 38 profissionais de enfermagem, entre os meses de março a julho de 2016, em três hospitais regionais localizados no Nordeste do Brasil. Realizou-se a análise de conteúdo dos dados. Resultados: Da análise emergiram duas categorias: assistência de enfermagem prestada às pessoas privadas de liberdade no contexto hospitalar e autoavaliação da assistência de enfermagem prestada às pessoas privadas de liberdade. Considerações finais: A assistência de enfermagem prestada às pessoas privadas de liberdade no ambiente hospitalar limita-se a procedimentos técnicos, demonstrando um processo-de-trabalho fragmentado e aquém do preconizado pelas políticas públicas vigentes. Identificou-se que a carência estrutural, sobretudo no tocante à segurança no ambiente hospitalar, associada à falta de capacitação dos profissionais para lidar com esta clientela dificultam a assistência de enfermagem nesse contexto.

Descritores: Assistência de Enfermagem; Assistência Hospitalar; Prisioneiros; Prisões; Saúde Pública.

\section{RESUMEN}

Objetivos: Describir la atención de enfermería a las personas privadas de libertad (PPL) en el ambiente hospitalario. Métodos: Estudio exploratorio, descriptivo, de enfoque cualitativo, en el cual participaron 38 profesionales de enfermería, realizado entre marzo y julio de 2016 en tres hospitales regionales situados en el Nordeste de Brasil. Se realizó el análisis de contenido de los datos. Resultados: En el análisis se encontró dos categorías: Atención de enfermería a las personas privadas de libertad en el contexto hospitalario y Autoevaluación de la atención de enfermería a las PPL. Consideraciones finales: La atención de enfermería a las personas privadas de libertad en el ambiente hospitalario se restringe a procedimientos técnicos, lo que demuestra ser un proceso de trabajo fragmentado y por debajo del recomendado por las políticas públicas vigentes. Se identificó que la carencia estructural, sobre todo en lo que se refiere a la seguridad en el ambiente hospitalario, asociada a la falta de capacitación de los profesionales para lidiar con esta clientela, dificulta la atención de enfermería en ese contexto. Descriptores: Atención de Enfermería; Atención Hospitalaria; Prisioneros; Prisiones; Salud Pública. 


\section{INTRODUCTION}

Interpersonal care is the oldest practice in the history of mankind, whose purpose is to ensure the continuity of life by guaranteeing human vital functions. Thus, care practices, such as the provision of food or substances for curative purposes to cope with diseases, have a cultural character, transmitted from generation to generation. However, beginning in the nineteenth century, care practices to prevent or cure diseases underwent a process of professionalization, coming to be considered an attribute of health professionals, especially those of nursing ${ }^{(1-2)}$.

Nursing care is considered one of the pillars of health practices, necessary for the promotion, prevention, treatment and rehabilitation of individuals and the community ${ }^{(3-4)}$. Therefore, it is expected that, in assisting users, nursing professionals base their practices on scientific knowledge, but also consider humanization as the essence of technical and ethical action in health practices ${ }^{(5)}$.

As regards health care for persons deprived of liberty (PDL), we highlight the recommendations of the Brazilian Penal Execution Act (LEP) ${ }^{(6)}$, which deals with the right to health of people in prison settings, with guarantee of curative and preventive actions, comprising medical, pharmaceutical and dental care. In addition, LEP determines referral of prisoners to establishments in the health care network, in situations where the prison health facility cannot be effective.

Also within the scope of the legislation on care to PDL, the Ministry of Justice, in partnership with the Ministry of Health, instituted the National Health Plan of the Penitentiary System (PNSSP), through Interministerial Ordinance No. 1,777, dated September 9, 2003, aiming to promote integral attention to the population confined in male and female prisons, including the psychiatric facilities ${ }^{(7)}$. In 2014, with the purpose of expanding the health actions of the Unified Health System (SUS) for the liberty-deprived population, the Ministry of Health launched the National Policy for Comprehensive Health Care for Persons Deprived of Liberty in the Prison System (PNAISP) ${ }^{(8)}$.

However, it is noteworthy that despite the legal apparatus, prison health care in Brazil faces quantitative difficulties, with low percentage of prison units with health teams in place, as well as qualitative difficulties, mainly with unskilled professionals and fragmented network care ${ }^{(9-10)}$.

In addition to the above-mentioned difficulties, and to social vulnerability prior to imprisonment, we note aspects that enhance illness processes, such as overcrowding, sanitation, insufficient food and exposure to stress and violence, with hospital treatment often needed because health promotion and protection actions have proved quite ineffective in this context $\mathrm{t}^{(11-12)}$.

The need to train the nursing team's skills and competencies to attend to PDL justifies this study. Denying the importance of the topic, and sweeping health analyses of the prison system under the carpet can mean acceleration of system depletion and worsening of the situation. Therefore, discussing the topic may be the beginning of a transformation process that starts in the academy and extends its reflections to the social context.

\section{OBJECTIVES}

Describe the nursing care provided to persons deprived of liberty in the hospital environment.

\section{METHODS}

\section{Ethical aspects}

The data presented here is part of the thesis developed in the Associate Graduate Nursing Program of Universidade Estadual de Pernambuco (UPE) and in Universidade Estadual da Paraíba (UEPB), entitled "Hospital care for convicts: Nursing practices and health policies".

After a favorable opinion from the Departments of Penitentiary Administration and Hospital Institutions involved in the study, the project was approved by the Research Ethics Committee of UBB and is compliant with Resolution 466/2012 ${ }^{(13)}$. In order to safeguard the confidentiality of the research subjects, as well as the institutions visited, an alphanumeric code identification system was adopted, with hospitals identified by letters of the Greek alphabet $(\alpha, \beta, y)$, Nurses by "N" and Nursing Technicians by "NT", followed by the number indicating the interview completion order.

\section{Study design}

This is a descriptive, exploratory research with a qualitative approach, a design that is suitable to capture subjective experiences of certain events ${ }^{(14)}$.

\section{Study scenario}

The study was carried out in the medical and surgical wards of three public hospitals located in the northeastern regions of Brazil, namely: Paraíba, Pernambuco and Rio Grande do Norte. These institutions are references for urgency and emergency care and are intended to SUS users, including liberty-deprived persons.

Of the three institutions surveyed, only one had a specific ward for PDL, which was separated by bars from the other hospital spaces. In the other institutions visited, inmates shared the same wards with other patients according to one single criterion: diagnosis/medical treatment. In the three hospitals, the nursing team followed a monthly timetable in the sectors, but the number of patients attended by each nursing technician was set by the professional nurse at the beginning of the work shift.

It should be added that PDL were accompanied by security agents (military police officers), who kept guard outside the ward throughout the hospitalization period and accompanied the nursing professional during care. In addition, some inmates were handcuffed to beds because they were considered as highly dangerous.

\section{Data source}

Survey participants were nurse team members who met the following inclusion criteria: be nurses or nursing technicians who worked in the Medical and Surgical Wards of said hospitals and who had been attending to PDL for at least six months. Professionals who were on vacation or medical leave during the collection period were excluded. After considering the theoretical saturation of statements ${ }^{(15)}, 38$ professionals participated in the study: 17 nurses and 21 nursing technicians. 


\section{Data collection}

Data production occurred from March to July, 2016, from semistructured audio-recorded interviews held in private rooms at the respective institutions and based on the following guiding questions: How does the nursing care provided to persons deprived of liberty occur in this institution? How do you evaluate the care (assistance) delivered by the nursing professionals?

The research subjects were identified in loco, who were invited to participate in the study after being explained about the aims of the research. Those meeting the previously established inclusion criteria were interviewed at the nursing units of each institution at their convenience. Interviews were audio taped and fully transcribed immediately after completion, so as not to lose relevant information for data analysis.

\section{Data analysis}

Data analysis was concomitant to collection and used the content analysis technique proposed by Bardin ${ }^{(16)}$, completing three phases as recommended: pre-analysis, to get a first impression of the data collected, which in turn is subdivided into four stages, namely: floating reading , choice of documents, hypotheses, objectives, and construction of indicators; the exploratory phase, in which the material was codified into categories by means of clippings of the records; and the third and last phase, in which the data were treated through critical and reflexive evaluation.

\section{RESULTS}

The following categories emerged from data analysis: nursing care provided to PDL in hospitals and self-assessment of the nursing care delivered to PDL, which will be described below, with the emerging concepts, through participants' statements.

\section{Category I - Nursing care provided to persons deprived of liberty in the hospital setting}

The care provided by the nursing team to liberty-deprived persons in the hospital setting is limited to meeting this clientele's basic needs, namely: bath, dressings, food and medicalization, to guarantee the prompt recovery, as demonstrated by the following statements:

Well, here we share the work. The technician does the medicating, general care and bathing in the bed. The nurse is in charge of catheterization, pump medication, complex things. Each one does their best for recovery as fast as possible. (a NT3)

The care practices are the same for all patients, but with the custodial ones (as we call them here) the focus is on medication administration, dressings, and intimate hygiene as the patient's curative actions. (y NT7)

Bath in the bed, medication administration, catheter passage, and dressing. Everything that has to be done by nursing, prescribed by the doctor, we do. (N2)

\section{Category II - Self-evaluation of nursing care provided to per- sons deprived of liberty}

This category included the overall evaluation of the nursing staff on aspects related to care delivered to hospitalized PDL.

I find it a bit flawed. There is a lack of preparation to have a relationship, a dialogue with the patient, we need such guidance. The patient deserves care like anyone, whatever he/she did. But therapeutic communication does not exist. With them there is fear. On the one hand we are sorry. On the other, fear, anger. Mixed feelings. ( $\beta$ N4)

The evaluation about care is positive. We do what they need. But we have never been trained for this emotional, behavioral part. ( $\beta$ N5)

The evaluation would only be positive if both patients and professionals were well at the end. The patients do get well, as they receive the care their body needs. But the professionals, as they find they were assigned to inmate care, they become afraid, it means suffering. They suffer from body aches, professionals suffer in fear. Doing a procedure with piercing equipment, scalp, surrounded by them, is very challenging. That is why my evaluation is negative. We take care of them, but who takes care of us? There is that fear, that psychological pressure, I never go in there alone, I always call a colleague. (y NT6)

The distinction in the care provided to PDL and other patients emerges in some statements and indicates that the patient's dangerousness directly affects the practices developed by the nursing team.

Treatment is different because we have a certain fear, because we are aware that we must watch out. They are inmates! They are prisoners! Sometimes they are in revolt, they have come from prison. (a NT1)

There is a difference, indeed. I'd be lying if I said otherwise. In the treatment, in the way, if I have a medicine, only one, and I have to choose, I will give it to someone else. Not to an inmate! He will be the last to be benefited. Because many are here after clashes with cops or thugs. ( $\beta$ NT2)

Boy, look, honestly, sometimes I feel a difference. I usually try not to learn what he did, but we end up learning. Then one of these days a rapist got here. He raped a five-year-old. Raped and killed! So, we look at a person like that, I have a daughter, and we try hard to take care of them. We do the very basic, technical, mechanical, so that neither he nor the family can complain. ( $\beta \mathrm{E} 1)$

In general, we have a certain care, a certain caution about materials when we are going to do some procedure. Try to keep, say, a scalpel, out of reach if it is some kind of invasive procedure, after all it can be used against us. This is not a concern in the other wards. When I'm in the inmates' ward, I take it as a punishment. Being on duty is hell. ( $\beta \mathrm{E} 3)$

Some interviewees claim that they organize and deliver care without distinction, regardless of whether the subject has broken the law, as in the following statements: 
We try to treat them the same way. All the care that is done with the other patients is done with them as well, after all it is about human rights, isn't it? Even being afraid, with that psychological pressure, because they do stare at us. (y NT6)

I treat everyone the same because to me everyone is a patient. There is no inmate or family parent, no. For me they are all the same. ( $\beta$ NT1)

It is the same care as if it were with others, because regardless of what he did he is a human being equal to anyone. And we must show respect because he is here to be cared for and not to be mistreated, tried or acquitted. ( $\beta$ NT5)

The interviewees signaled the lack of hospital structure, with emphasis on the professionals' safety as a factor that interferes with the care provided:

Look, if there is no disoriented inmate that may compromise, that may really pose some threat to care delivery, it is okay. But if the inmate ward is overcrowded as it is today, with six patients where there should be only three, it 's complicated. We do fear for safety. It's like working in an overcrowded prison. (a E8)

We have some problems. There are some policemen who are good and when we have to go in there they come in with us. Sometimes folks get in there and they stand outside and do not get in. It has already happened, of technicians getting in at medication time and they shut the bars behind them. They got locked in there with inmates while they were outside, that's not right. One of the technicians has never come back to the hospital. (a E4)

\section{DISCUSSION}

The results of this research allowed to identify aspects about the nursing care provided to PDL, which is limited to technical procedures, demonstrating a fragmented work process that falls short of the current standards advocated by public policies.

It is known that the Flexnerian paradigm, influential and still present in the health area, is characterized by a technicist, biologistic perspective, focused on curative actions by the nursing team, to the detriment of a holistic and humanized practice $^{(17-19)}$. In this context, the care practice developed in hospitals demonstrates that nursing professionals have exercised their care practices only in search of cure, with care restricted to performing procedures, mechanized, fragmented work, absence of communication with patients, absence of clinical evaluation, and vague progresses.

The reality identified in this research contradicts not only PNAISP recommendations as to the completeness of care to PDL, but what is recommended for good nursing care, i.e., the intersection between social, technical, managerial and scientific skills $s^{(8,18-19)}$.

Nursing professionals should guide their practices according to quality standards and ethical principles, understanding that health care accountability is not restricted to the technical act of offer, but also involves commitment with the quality of life of the assisted individual(20).

As provided in PNAISP, care should be comprehensive and promote qualified and humanized attention ${ }^{(7)}$. For doing so, it is coherent that the professional's caring actions with the freedom-deprived patient should be marked by commitment, equity, effectiveness, dignity, competence and responsibility.

Another relevant aspect for the quality of nursing care to PDL concerns the availability of trained human resources and the implementation of the Nursing Care Systematization (SAE) in the hospital context ${ }^{(21)}$.

The complexity of the nurse's practice is recognized, of the care that permeates this practice and of the doing as daily action in the care of individuals in the hospital environment. Such complexity is compounded by the discomfort mentioned by professionals in caring for PDL and the recognized inadequate number of professionals to guarantee nursing care. These aspects demonstrate the need for a fruitful debate on hospital care for prisoners and the role of nurses.

The interviews have shown services with compromised care, absence of specific qualification for the care of PDL, deficiency in the training courses, with curricula that do not teach skills and abilities to attend to PDL in the hospital environment, as well as lack of initiatives and updating of hospital institutions about the increasing demands in the work process.

Nursing professionals who work in direct care, even if occasional, recognize difficulties in the task of caring for inmates as triggers of feelings of guilt, sadness, anxiety, anger and powerlessness, similar to those experienced by nursing professionals who care for terminally ill patients ${ }^{(22)}$.

It is thus inferred that nursing professionals do not feel emotionally and behaviorally prepared to fully care for this group of subjects. Besides the stress of the nursing work process, the professional must know how to deal with the emotional stress related to the patient's condition of prisoner. These copings can compromise workers' quality of care and psychological structure ${ }^{(22)}$.

In the studied scenario, the non-establishment of interpersonal relations has repercussions on comprehensive care, humanization and preservation of ethical issues that permeate the professional practice ${ }^{(23)}$. According to the literature, communication is the basis of the therapeutic relationship. However, in the hospitals studied, the constant fear in relation to PDL and family, the imminent coexistence with confrontations between them and security agents, and the fear of causing dissatisfaction with an unmet request, cause the professionals to avoid establishing a relationship.

The subjects of this research have assessed their practices negatively due to the complete absence of bonds, breach of confidentiality - since professionals perform the service only in the presence of a security guard -, and the naturalization of bed restraints. Like the professionals in the study of Kuhn, Lazzari and Jung ${ }^{(24)}$, some members of the nursing team seem to adopt mechanization, detachment, rationalization and depersonalization of care, depriving subjects of any other meaning.

For this reason, the training of skills and competencies should be stimulated for the care of PDL in the hospital environment, so that the stigma about those who break criminal law, safety rules, inadequate psychological preparation, fear, and shortage of professionals do not compromise the service, from the modification of the work process and non-limitation of health actions.

The important role of continuing education to mobilize the potential of nursing workers is evidenced, since, by rescuing a conception aimed at the development of these professionals, it allows 
a permanent improvement of the quality of health care and the constitution of critical, ethical and humanistic technical practices ${ }^{(25)}$.

The National Policy on Permanent Education in Health, instituted by Administrative Rule GM/MS 198/04, aimed to constitute a teaching-learning network in the exercise of work in the SUS for the training and development of workers, based on the health needs of users/ population, while emphasizing the interdisciplinarity of the health team, focused the practice as a source of knowledge and placed the professional to act actively in the educational process ${ }^{(25)}$.

We have seen that the care delivered by the nursing team changes according to the users and is related to the type of crime committed and the establishment of empathy with the subject, which consequently affects the quality of care. In a study on health care work with convicted patients, the social condition of lawbreaker was shown to be present at all times, creating a conflicting relationship, because if the patient's condition is undeniable, but momentary, the transgression may be a relapse, a fact that arouses an antagonistic feeling in the professionals, between the patient and the "criminal"(26).

In this study, despite several difficulties in establishing a positive interaction, it was possible to identify some of the interviewees' statements that construe the individual situation of the convicted patient as that of any human being, abstracting the inmate condition at the time of care.

All care and attitudes in exercise by the nursing professional should aim at preserving respect, valuing life, quality of life, and human dignity; and all this regardless of who is being provided nursing care $^{(27)}$.

In addition, PDL have lost their right to come and go, but maintain all other fundamental rights protected and guaranteed by the State, including health care, from the PNAISP guidelines regarding the SUS, namely: integrality, intersectoriality, decentralization, hierarchy, and humanization ${ }^{(7)}$.

However, we found that some nursing professionals of the services surveyed face some difficulties in carrying out their patient care activities. The interviews have shown a concern with the physical integrity and safety of health care workers.

For the interviewees, the lack of partnership and harmony with the security agents is a complicating factor for performing their job. Increased interaction would favor the sense of protection and thus benefit the care of patients in seclusion in the hospital environment.

Care delivery is thus contingent on the overt presence of the security service, under the aegis of security first and then any other needs of PDL, including health care ${ }^{(28)}$.
Therefore, it is understood that the nursing team should base their practice in the care of PDL on biosafety recommendations, but should also maintain ethical conduct and guarantee the right to health and human dignity, respecting the principles that govern their professional practice. After all, caring is essential for the human life of healthcare professionals and users in need of care.

This demonstrates the urgent need to establish moments of evaluation of the service provided in order to reach forms of collective action from the perspective of the interdisciplinary look and action, necessary for understanding the complexity of health care.

\section{Limitations of the study}

Collection of data limited to medical and surgical clinics are considered as limitations of this study, and the results obtained cannot be generalized.

\section{Contributions to the field of nursing, health or public policy}

It is expected that the results of this study, in revealing the nursing professionals' evaluation of their practices, can contribute to the implementation of continuing education initiatives and, therefore, changes in the work process and qualification of care. Finally, we suggest that further studies should be carried out, widening the scope and including the identification of organizational and legal barriers that interfere with the care delivered to PDL.

\section{FINAL CONSIDERATIONS}

The nursing care provided to PDL in hospital settings is limited to technical procedures, demonstrating a fragmented work process that falls short of the standards advocated by current public policies. Structural deficiency was identified, especially with regard to safety in the hospital environment, which, coupled with the lack of training of professionals to deal with this clientele, hinder effective nursing care in this context.

We conclude on the necessity of including issues related to prison health in the curricular components and student training activities of technical and university nursing courses, geared towards guaranteeing the training of skills and competencies for a comprehensive and humane professional approach to this clientele. In addition, we point out the importance of continuing education initiatives for nursing professionals about the health care of liberty-deprived persons.

\section{REFERENCES}

1. Pereira LSM, Soares SM. Factors influencing the quality of life of family caregivers of the elderly with dementia. Ciênc Saúde Colet. 2015;20(12):3839-51. doi: 10.1590/1413-812320152012.15632014

2. Carlos DJD, Padilha MI, Villarinho MV, Borestein MS, Maia ARCR. Nursing Schools in northeastern Brazil (1943-1975). Rev Rene. 2014;15(2):326-33. doi: 10.15253/2175-6783.2014000200018

3. Oliveira LV, Leite NL, Cavalcante CAA, Miranda FAN. The care for inmates under the viewpoint of nursing students. Rev Pesqui: Cuid Fundam. 2016;8(1):3780-92. doi: 10.9789/2175-5361.2016.v8i1.3780-3792

4. Waldow VR. Enfermagem: a pràtica do cuidado sob o ponto de vista filosófico. Investig Enferm. Imagen Desarr. 2015;17(1):13-25. doi: 10.11144/Javeriana.IE17-1.epdc 
5. Rodrigues JAP, Lacerda MR, Favero L, Gomes IM, Méier MJ, Wall ML. Model of transpersonal caring in nursing home care according to Favero and Lacerda: case report. Rev Gaúcha Enferm. 2016;37(3):e58271. 10.1590/1983-1447.2016.03.58271

6. Ministério da Saúde (BR). Secretaria de Atenção à Saúde. Departamento de Ações Programáticas Estratégicas. Plano Nacional de Saúde no Sistema Penitenciário. [Internet]. Brasília: Ministério da Saúde; 2005. [cited 2017 Feb 08]. Available from: http://bvsms.saude.gov.br/bvs/ publicacoes/plano_nacional_saude_sistema_penitenciario_2ed.pdf

7. Ministério da Saúde (BR). Política Nacional de Atenção à Saúde das Pessoas Privadas de Liberdade no Sistema Prisional. Portaria n¹, de 2 de janeiro de 2014. [Internet]. Brasília: Ministério da Saúde; 2014. [cited 2017 Feb 08]. Available from: http://bvsms.saude.gov.br/bvs/ saudelegis/gm/2014/pri0001_02_01_2014.html

8. Minayo MCS, Ribeiro AP. Health conditions of prisoners in the state of Rio de Janeiro, Brazil. Ciênc Saúde Colet. 2016;21(7):2031-40. doi: 10.1590/1413-81232015217.08552016

9. Silva MBB. Emergence of a Policy, closure of a sector: regarding the management of penitentiary health care in Brazil. Ciênc Saúde Colet. 2016;21(7):2021-30. doi: 10.1590/1413-81232015217.00162016

10. Martins ELC, Martins LG, Silveira AM, Melo EM. The contradictory right to health of people deprived of liberty: the case of a prison in Minas Gerais. Saúde Soc. 2014;23(4):1222-34. doi: 10.1590/S0104-12902014000400009

11. Barsaglini RA, Kehrig RT, Arruda MB. Analysis of the perception of managers on management of Prison Health Policy in Mato Grosso, Brazil. Saúde Soc. 2015;24(4):1119-36. doi: 10.1590/S0104-12902015138278

12. Zoboli ELCP, Schveitzer MC. Nursing values as social practice: a qualitative meta-synthesis. Rev Latino-Am Enfermagem. 2013;21(3):695-703. doi: 10.1590/S0104-11692013000300007

13. Ministério da Saúde (BR). Resolução n 466/12, de 12 de dezembro de 2012. Dispõe sobre pesquisa envolvendo seres humanos [Internet]. Brasília: Ministério da Saúde; 2012 [cited 2017 Feb 08]. Available from: http://bvsms.saude.gov.br/bvs/saudelegis/cns/2013/ res0466_12_12_2012.html

14. Minayo MCS, Gomes SFDR. Pesquisa social: teoria, método e criatividade. 34th ed. Petrópolis: Vozes; 2015.

15. Fontanella BJB, Luchesi BM, Saidel MGB, Ricas J, Turato, ER, Melo DG. Sampling in qualitative research: a proposal for procedures to detect theoretical saturation. Cad Saúde Pública. 2011;27(2):389-94. doi: 10.1590/S0102-311X2011000200020

16. Bardin L. Análise de conteúdo. São Paulo: Edições 70; 2011.

17. Soares MI, Camelo SHH, Resck ZMR, Terra FS. Nurses' managerial knowledge in the hospital setting. Rev Bras Enferm. 2016;69(4):631-7. doi: 10.1590/0034-7167.2016690409i

18. Montezeli JH, Haddad MCF, Lourenço AM, Matsuda LM. Approximations between social skills, nursing care management and complex thinking. Rev Min Enferm. 2018;22:e-1092. doi: 10.5935/1415-2762.20180022

19. Bresciani HR, (Org). Legislação comentada: lei do exercício profissional e código de ética [Internet]. Florianópolis: Conselho Regional de Enfermagem de Santa Catarina (Coren/SC);2016 [cited 2017 June 26]. Available from: http://www.corensc.gov.br/wp-content/ uploads/2016/11/Legisla\%C3\%A7\%C3\%A3o-Comentada_site.pdf

20. Ferla AA, Rocha CMF. Inovações na formação de sanitaristas. Porto Alegre: Rede Unida; 2013.

21. Pedreira, MLG. Evidence-based practice to promote patient safety. Acta Paul Enferm. 2009;22(spe):880-1. doi: 10.1590/ S0103-21002009000700007

22. Rosa DSS, Couto SA. The coping emotional professional nursing in patient care in the process of life terminality. Rev Enferm Contemp. 2015;4(1):92-104. doi: 10.17267/2317-3378rec.v4i1.467

23. Camelo SHH. Professional competences of nurse to work in Intensive Care Units: an integrative review. Rev Latino-Am Enfermagem. 2012;20(1):192-200. doi: 10.1590/S0104-11692012000100025

24. Kuhn T, Lazzari DD, Jung W. Experiences and feelings of nursing professionals in caring of the dead patient. Rev Bras Enferm. 2011;64(6):1075-81. doi: 10.1590/S0080-623420140000100004

25. Bezerra ALQ, Queiroz ES, Weber J, Munari DB. The process of continuing education from the perspective of nurses of a university hospital. Rev Eletr Enf. 2012[cited 2017 Mar 28];14(3):618-25. doi: 10.5216/ree.v14i3.12771

26. Irala DA, Vaz-Cezar MR, Cestari M.E. Health care work with prisoners: metaphorical meanings created in the hospital context. Acta Paul Enferm. 2011;24(2):206-12. doi: 10.1590/S0103-21002011000200008

27. Carmo HO, Araújo CLO. Elderly population in the prison system: a look behind bars. Rev Kairós Gerontol. 2011;14(6):183-94. Available from: https://revistas.pucsp.br/index.php/kairos/article/view/11707

28. Silva e Souza MO, Passos JP. The nursing practice inside the penal system: limits and possibilities. Esc Anna Nery Rev Enferm. 2008;12(3):41723. doi: $10.1590 / S 1414-81452008000300004$ 